\title{
ISOLASI DAN IDENTIFIKASI JAMUR ENTOMOPATOGEN SEBAGAI KANDIDAT BIOINSEKTISIDA LALAT RUMAH (MUSCADOMESTICA)
}

\author{
Nofita Se ptiana $^{1^{*}}$, Emantis Rosa $a^{2}$, Chris tina Nugroho Ekowati ${ }^{3}$ \\ ${ }^{1,2,3}$ Jurusan Biologi FMIPA Universitas Lampung, Indonesia \\ *Email: nofitaseptiana@gmail.com
}

Received: May6 ${ }^{\text {th }}$, 2019. Accepted: June $30^{\text {th }}$, 2019. Published: June $30^{\text {th }}, 2019$

\begin{abstract}
House flies (M. domestic) are mechanical vectors of various diseases by microbial pathogens including Salmonella which causes typhoid fever, Shigella causes dysentery, and E. coli causes diarrhea. Generally, controlling $M$. domestic uses synthetic insecticides, but it causes resistance and has a negative impact on the environment. Therefore, there is a need for alternative control, namely biological control using entomopathogenic fungal isolates as bioinsecticides. This study begins with the isolation of entomopathogenic fungi using the moist chamber method with fly house larvae as insect bait. Fungus that grow on larvae are cultured and purified on PDA medium and then identified. Identification was carried out through macroscopic observations including colony color and diameter and microscopic observations including conidia, conidiophores, hyphae, vesicles, fialids, and leg cells. The results of isolation and identification obtained five types of isolates, namely Aspergillus sp. 1, Aspergillus sp. 2, Geotrichum sp., Penicillium sp., and Aspergillus sp. 3.
\end{abstract}

Keywords: entomopatogenic fungi; identification; isolation; M. domestica

\begin{abstract}
Abstrak
Lalat rumah $(M$. domestica) merupakan vektor mekanik berbagai penyakit oleh mikroba patogen antara lainSalmonella penyebab demam tifoid, Shigella penyebab disentri, dan E. coli penyebab diare. Pengendalian $M$. domesticaumumnya menggunakan insektisida sintetis, namun menimbulkan resistensi dan berdampak buruk bagi lingkungan. Oleh karena itu, perlu dilakukan pengendalian alternatif berupa pengendalian biologi menggunakan isolat jamur entomopatogen sebagai bioinsektisida. Penelitian ini diawali dengan isolasi jamur entomopatogen menggunakan metodemoistchamberdengan larva $M$. domestica sebagai serangga pancingan. Jamur yang tumbuh pada larva dikultur dan dimurnikan pada media PDA lalu diidentifikasi. Identifikasi dilakukan melalui pengamatan makroskopis meliputi warna dan diameter koloni dan pengamatan mikroskopis meliputi struktur konidia, konidiofor, hifa, vesikula, fialid, dan sel kaki. Hasil isolasi dan identifikasi diperoleh lima jenis isolat yaitu Aspergillussp. 1, Aspergillussp. 2, Geotrichumsp., Penicilliumsp., dan Aspergillussp. 3.
\end{abstract}

Kata kunci : identifikasi; isolasi; jamur entomopatogen; M. domestica.

\section{PENDAHULUAN}

Lalat rumah (Muscadomestica) memiliki kisaran tempat hidup yang luas (Astuti \& Pradani, 2010; Ihsan, 2016). M. domestica mempunyai siklus hidup singkat dan daya reproduksi tinggi sehingga populasinya dapat meningkat dengan pesat (Astuti \& Pradani, 2010). Tingginya jumlah populasi $M$. domestica dapat mempengaruhi higienitas dan nilai estetika lingkungan (Masyhuda, Hestiningsih, \& Rahadian, 2017). Hal ini karena $M$. domestica berperan sebagai vektor mekanik lebih dari 100 penyakit yang disebabkan oleh 
mikroba patogen diantaranya Salmonella, Shigella, Campylobacter, Escherichia, Enterococcus, Chlamydia. Penyakit yang umum ditimbulkan yaitu demam tifoid, diare, dan disentri (Hastutiek \& Fitri, 2013). Oleh sebab itu, perlu dilakukan pengendalian populasi $M$. domestica untuk mencegah penyebaran penyakit. Pengendalian yang umum dilakukan secara kimiawi dengan insektisida sintetis, namun penggunaan bahan kimia dalam dosis tertentu dapat menimbulkan resistensi dan menyisakan residu yang mencemari lingkungan (Ardiansyah \& Mahajoeno, 2002).

Berdasarkan informasi tersebut, perlu dilakukan pengendalian alternatif berupa pengendalian biologi yang tidak menimbulkan resistensi dan ramah lingkungan. Dalam prosesnya, dapat memanfaatkan agen hayati berupa jamur entomopatogen (Nunilahwati, Herlinda, Irsan, \& Pujiastuti, 2013; Rosmayuningsih, Rahardjo, \& Rachmawati, 2014). Jamur entomopatogen yang umum digunakan yaitu Bauveriabassiana (Hasyim, 2006; SOETOPO \& Indrayani, 2015), Metarhiziumanisopliae (Effendy, Septiadi, Salim, \& Mazid, 2011; Suprayogi, Marheni, \& Oemry, 2014), Verticillium (Ladja, Bulo, Santoso, \& Nurhayati, 2015; Prayogo, 2012). Hasil penelitian Yunizar, dkk., (2018) penggunaan $M$. Anisopliae isolat dari Orytesrhinoceros hanya dapat mengendalikan M. domestica $50 \%$. Oleh karena itu, perlu eksplorasi isolat jamur entomopatogen yang berasal dari $M$. domestica yang berpotensi dapat mengendalikan populasi $M$. domestica.

\section{METODE PENELITIAN}

Penelitian ini dilaksanakan di Laboratorium Mikrobiologi Jurusan Biologi, Fakultas Matematika dan Ilmu Pengetahuan Alam, Universitas Lampung. Bahan yang digunakan yaitu larva M. domestica, alkohol 70\%, spritus, media PotatoDextrose Agar (PDA), dan antibiotik kloramfenikol. Adapun Isolasi dan Identifikasi Jamur Entomopatogen adalah sebagai berikut:

Isolasi jamur dilakukan dengan metode Moistchamber dengan cara larva $M$. domestica yang telah mati diletakkan di atas tisu basah dalam cawan steril (Gambar 1) kemudian diinkubasi selama 7 hari pada suhu $25-28^{\circ} \mathrm{C}$ (Reddy, Antwi, Shrestha, \& Kuriwada, 2016). Jamur yang tumbuh dikultur pada media PDA selama 3 hari (Gambar 2).

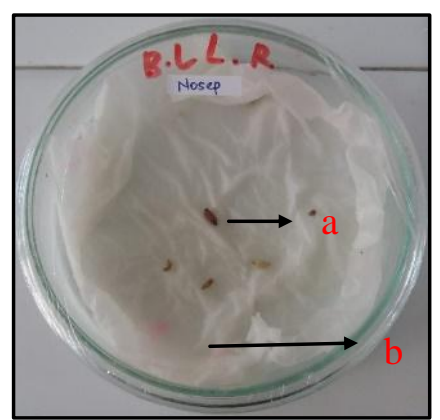

Gambar 1. Metode Moistchamber: (a) Larva M. domestica berjamur, (b) tisu basah 


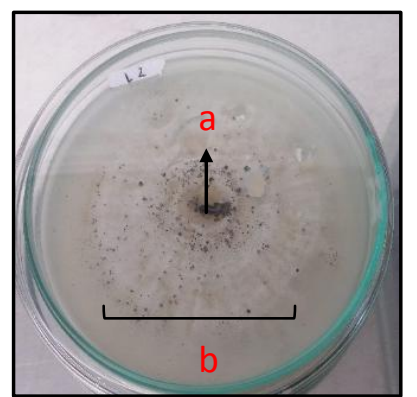

Gambar 2. Kultur Jamur pada Media PDA: (a) larva M.domestica, (b) koloni jamur

Isolat yang tumbuh pada PDA kemudian dimurnikan. Isolat murni diidentifikasi secara makroskopis dan mikroskopis. Pengamatan makroskopis meliputi warna dan diameter koloniumur 5 hari. Pengamatan mikroskopis melalui teknik slideculture yang diinkubasi selama 48 jam pada suhu $25-28^{\circ} \mathrm{C}$ (Nadhifah, Hastuti, \& Syamsuri, 2016). Pengamatan meliputi struktur konidia, konidiofor, ada tidaknya sekat pada hifa, vesikula, fialid, dan ada tidaknya sel kaki (Yang et al., 2010).

\section{HASIL DAN PEMBAHASAN}

Berdasarkan hasil isolasi, diperoleh lima isolat jamur entomopatogen dengan kode IL1, IL2, IL3, IL4, dan IL5 yang ditampilkan pada Gambar 3.pengamatan koloni isolat jamur entomopatogen adalah sebagai berikut.

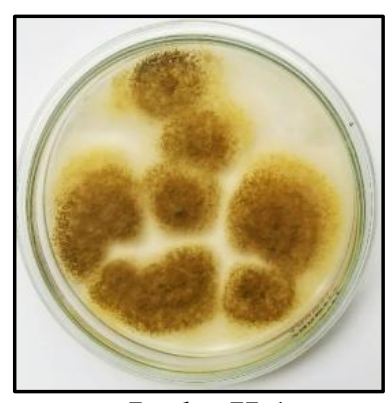

Isolat IL1

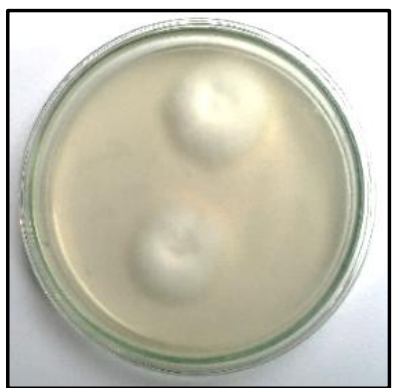

Isolat IL3

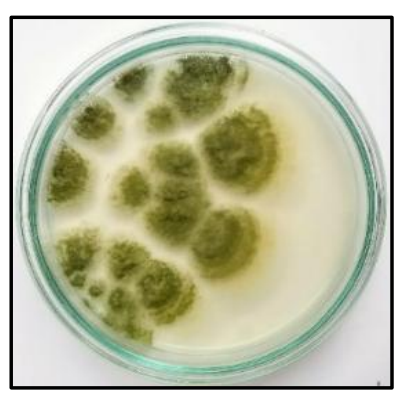

Isolat IL2

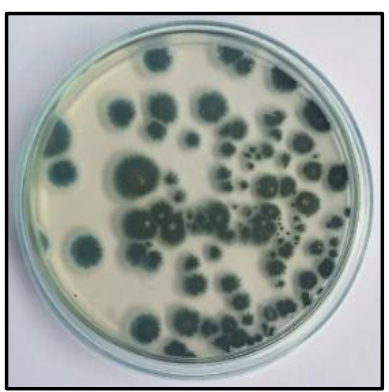

Isolat IL4 


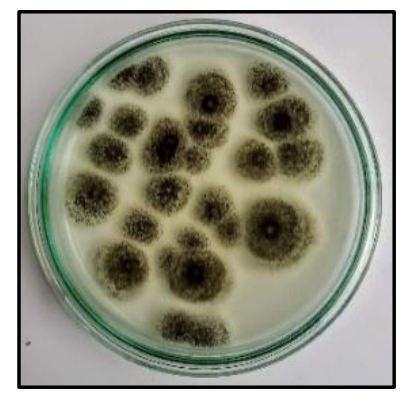

Isolat IL5

Gambar 3. Pengamatan Koloni Isolat Jamur Entomopatogen,

Berdasarkan hasil pengamatan makroskopis, warna koloniisolat IL1 yaitu kuning kecokelatan. Bentuk koloninya tersebar pada cawan berisi media PDA. Isolat IL2 memiliki koloni berwarna hijau dengan bagian tepi kekuningan. Semakin tua umur koloni jamur, maka warnanya semakin hijau gelap. Isolat IL3 memiliki ciri-ciri maksrokopis yaitu koloni terdiri atas filamen-filamen berwarna putih seperti kapas dengan tepi yang halus dan rata. Isolat IL4 koloninya berwarna hijau ke abu-abuan dengan bagian tepi berwarna putih. Isolat IL5 berwarna hitam dengan bagian tepi berwarna putih. Permukaan koloninya kasar dan menyebar pada media PDA (Gambar 3).

Diameter koloni kelima isolat jamur entomopatogen diukur pada umur 5 hari pada Tabel 1 sebagaiberikut.

Tabel 1. Diameter Koloni Isolat Jamur Entomopatogen Umur 5 Hari.

\begin{tabular}{cc}
\hline Kode Isolat & Diameter koloni $(\mathrm{mm})$ \\
\hline IL1 & 32 \\
IL2 & 28 \\
IL3 & 28 \\
IL4 & 10 \\
IL5 & 20 \\
\hline
\end{tabular}

Kelima isolat jamur diamati secara mikroskopis melalui teknik slideculture. Morfologi mikroskopis isolat IL1 ditampilkan pada Gambar 4 sebagai berikut.

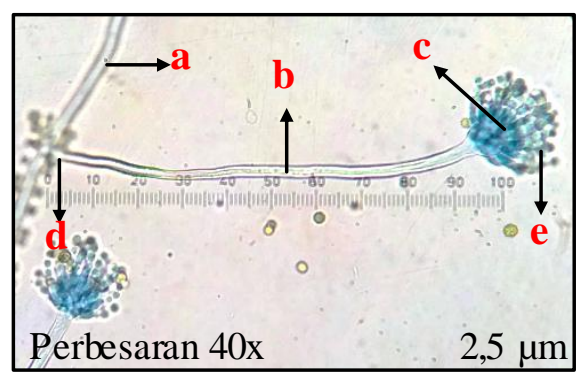




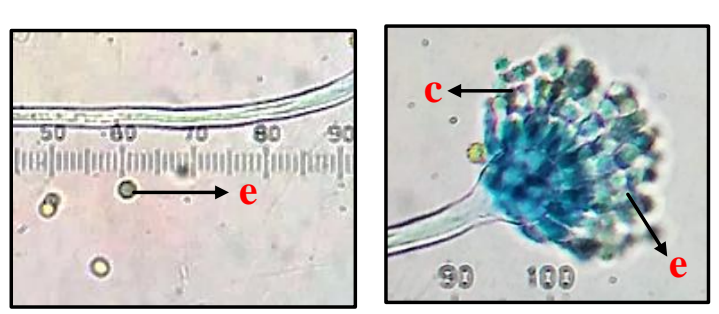

Gambar 4. Isolat IL1: (a) hifa, (b)konidiofor, (c)vesikula, (d) sel kaki, (e)konidia.

Berdasarkan Gambar 4. Di atas, isolatIL1 memiliki hifa yang bersekat dengan diameter 7,5 $\mu \mathrm{m}$. Konidiofornya hialin, tegak dan sederhana dengan panjang konidiofor $250 \mu \mathrm{m}$. Pada bagian atas konidiofor terdapat vesikula berbentuk semi bulat seperti gada dengan ukuran 22,5x17,5 $\mu \mathrm{m}$. Puncak konidiofornya dikelilingi oleh fialid berbentuk labu yang menempel pada vesikula. Konidianya bulat berantai pada ujung fialid tunggal, ukuran konidianya $6,25 \mu \mathrm{m}$.
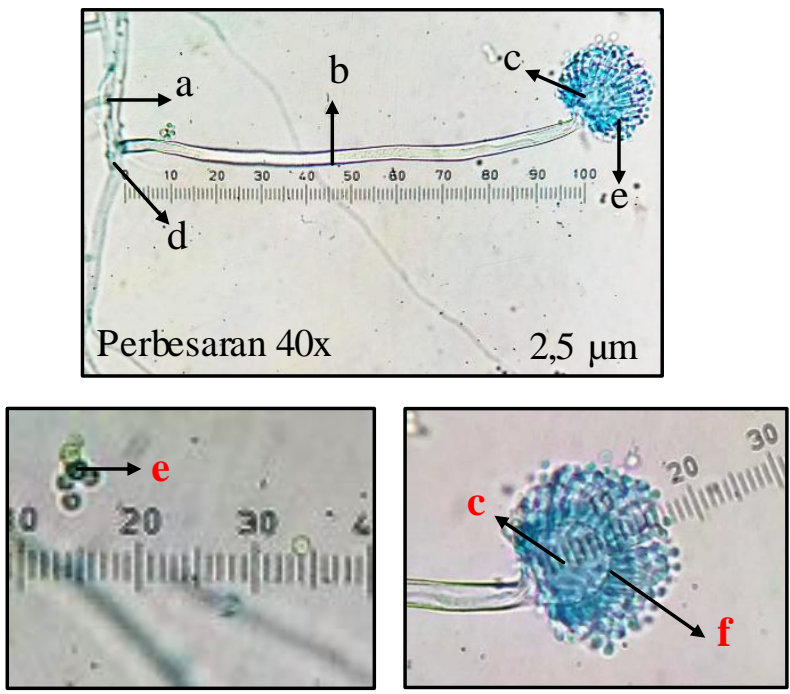

Gambar5.Isolat IL2: (a) hifa, (b)konid iofor, (c)vesikula, (d) selkaki, (e)konidia, (f)fialid.

Berdasarkan Gambar 5, dapat diketahui bahwa isolat IL2 memiliki ciri-ciri yaitu hifa bersekat dengan diameter 7,5 $\mu \mathrm{m}$. Panjang kondiofornya $275 \mu \mathrm{m}$, strukturnya tegak dan sederhana. Pada puncak konidiofor terdapat fialid tunggal yang me nempel pada vesikula. Vesikula berbentuk oval dengan diameter $25 \times 20 \mu \mathrm{m}$. Ukuran konidianya $5 \mu \mathrm{m}$ dengan bentuk bulat berantai pada ujung fialid berbentuk labu ditunjukan pada Gambar 5 sebagai berikut.

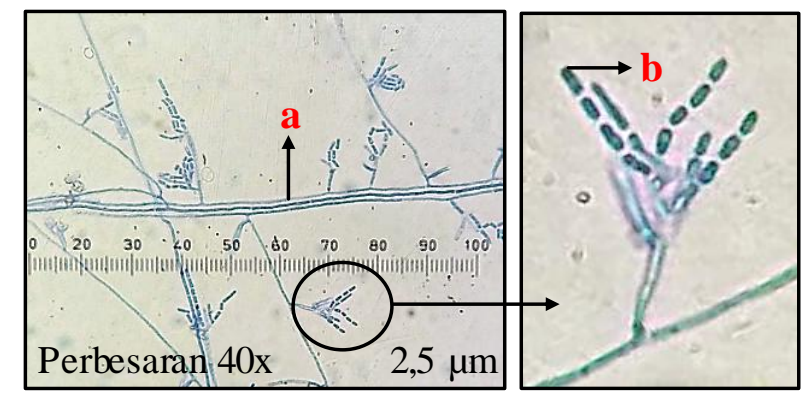

Gambar 6. Isolat IL3:(a) hifa, (b)konidia, 
Isolat IL3 terdiri atas hifa hialin yang bersekat-sekat dan tidak memiliki konidiofor. Konidia (arthospora) berbentuk silinder pendek atau menyerupai batang dengan ujung bersekat membentuk rantai, ukuran konidanya $5 \mu \mathrm{m}$ ditunjukan pada Gambar 6 sebagai berikut.

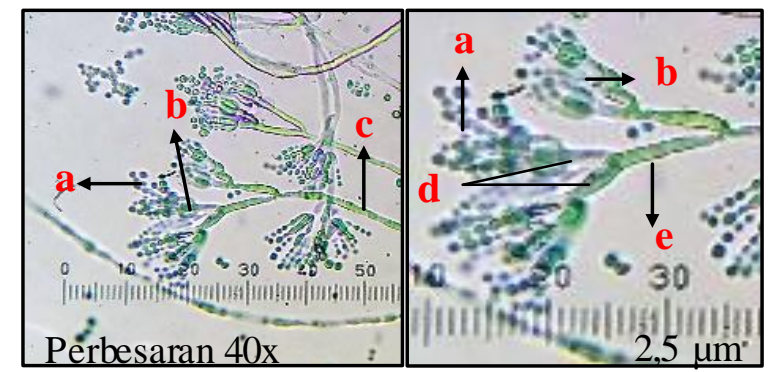

Gambar 7. Isolat IL4: a. konidia, b. fialid, c. hifa, d. metula, e. konidiofor.

Hasil pengamatan IL4, diketahui bahwa isolat IL4 memiliki struktur morfologi sepeti brush. Konidianya bulat silinder dengan diameter 2,5 $\mu \mathrm{m}$. Konidia membentuk untaian rantai dan berada pada ujung fialid tunggal. Terdapat percabangan metula yang menyokong fialid berbentuk labu. Konidiofornya tegak dan bercabang. Panjang konidiofornya yaitu 22,5-27,5 $\mu \mathrm{m}$.

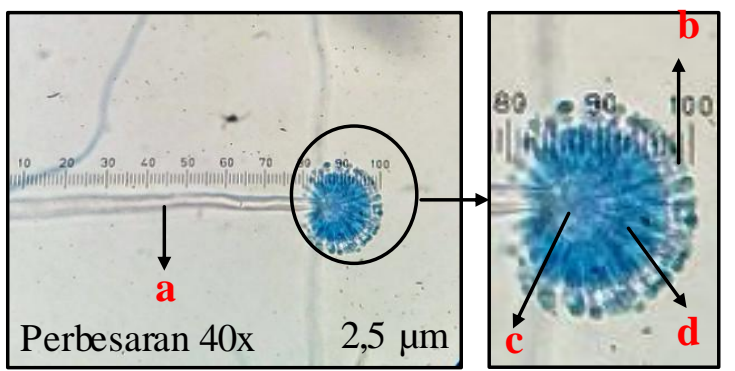

Gambar 8. Isolat IL5: (a) konid iofor, (b) konidia, (c) vesikula, (d) fialid.

Isolat IL5 memiliki hifa hialin dan tidak bersekat. Konidiofor Isolat IL5 tegak dan sederhana, panjangnya $255 \mu \mathrm{m}$. Vesikulanya berbentuk bulat dengan diameter $20 \mu \mathrm{m}$ yang dikelilingi oleh fialid berbentuk gada tunggal. Konidia berada di ujung fialid berbentuk bulat (Gambar 8). Hasil identifikasidisajikan pada Tabel 3.

Tabel 3. Karakter Isolat Jamur Entomopatogen Hasil Identifikasi

\begin{tabular}{|c|c|c|c|c|c|c|c|}
\hline $\begin{array}{l}\text { Kode } \\
\text { Isolat }\end{array}$ & $\begin{array}{c}\text { Struktur } \\
\text { konidia }\end{array}$ & Konidofor & Hifa & Vesikel & Fialid & Sel kaki & Kesimpulan \\
\hline IL1 & $\begin{array}{c}\text { Bulat } \\
\text { (globose) }\end{array}$ & $\begin{array}{c}\text { Tegak, } \\
\text { sederhana }\end{array}$ & Bersekat & $\begin{array}{l}\text { Semi } \\
\text { bulat }\end{array}$ & Tunggal & Ada & Aspergillussp. 1 \\
\hline IL2 & $\begin{array}{c}\text { Bulat } \\
\text { (globose) }\end{array}$ & $\begin{array}{c}\text { Tegak, } \\
\text { sederhana }\end{array}$ & Bersekat & Oval & Tunggal & Ada & Aspergillussp. 2 \\
\hline IL3 & $\begin{array}{l}\text { Silinder } \\
\text { pendek }\end{array}$ & Tidak ada & Bersekat & Tak ada & Tak ada & Tak ada & Geotrichumsp. \\
\hline $1 \mathrm{~L} 4$ & $\begin{array}{l}\text { Bulat } \\
\text { (globose) }\end{array}$ & Bercabang & Bersekat & Tak ada & Tunggal & Tak ada & Penicilliumsp. \\
\hline 1L5 & $\begin{array}{c}\text { Bulat } \\
\text { (globose) }\end{array}$ & $\begin{array}{c}\text { Tegak, } \\
\text { sederhana }\end{array}$ & Bersekat & Bulat & Tunggal & Ada & Aspergillussp. 3 \\
\hline
\end{tabular}




\section{SIMPULAN DAN SARAN}

Berdasarkan hasil identifikasi, diperoleh 5 jenis isolat jamur entomopatogen yaitu Aspergillussp. 1, Aspergillussp. 2, Geotrichumsp., Penicilliumsp., dan Aspergillussp. 3

Perlu dilakukannya uji lanjutan untuk mengentahui efektivitas isolat jamur sebagai kandidat bioinsek tisida $M$. domestica.

\section{DAFTAR PUSTAKA}

Ardiansyah, W., \& Mahajoeno, E. (2002). Toksisitas Ekstrak Daun Nimba (Azadirachta indica A. Juss) pada Anakan Siput Murbei (Pomacea canaliculata L.). BioSMART, 4(1), 29-34.

Astuti, E. P., \& Pradani, F. Y. (2010). Pertumbuhan dan Reproduksi Lalat Musca domestica pada Berbagai Media Perkembangbiakan. Aspirator Journal of Vector-Borne Diseases, 2(1).

Effendy, T. A., Septiadi, R., Salim, A., \& Mazid, A. (2011). Jamur entomopato gen asal tanah lebak di Sumatera Selatan dan potensinya sebagai agensia hayati walang sangit (Leptocorisa oratorius (F.)). Jurnal Hama Dan Penyakit Tumbuhan Tropika, 10(2), 154-161.

Hastutiek, P., \& Fitri, L. E. (2013). Potensi Musca domesticaLinn. Sebagai Vektor Beberapa Penyakit. Jurnal Kedokteran Brawijaya, 23(3), 125-136.

Hasyim, A. (2006). Evaluasi bahan carrier dalam pemanfaatan jamur entomopatogen, Beauveria bassiana (Balsamo) Vuillemin untuk mengendalikan hama penggerek bonggol pisang, Cosmopolites sordidus Germar. Jurnal Hortikultura, 16(3).

Ihsan, I. M. (2016). Pengaruh Suhu Udara terhadap Perkembangan Pradewasa Lalat Rumah (Musca domestica). Jurnal Teknologi Lingkungan, 17(2), 100-107.

Ladja, F. T., Bulo, L. P. P. T. J., Santoso, T., \& Nurhayati, E. (2015). Potensi Cendawan Entomopatogen Verticillium lecanii dan Beauveria bassiana dalam Mengendalikan Wereng Hijau dan Menekan Intensitas Penyakit Tungro.

Masyhuda, M., Hestiningsih, R., \& Rahadian, R. (2017). Survei Kepadatan Lalat Di Tempat Pembuangan Akhir (TPA) Sampah Jatibarang Tahun 2017. Jurnal Kesehatan Masyarakat (e-Journal), 5(4), 560-569.

Nadhifah, Y. M., Hastuti, U. S., \& Syamsuri, I. (2016). Isolasi, Karakterisasi, Dan Identifikasi Mikoflora Dari Rizosfer Tanah Pertanian Tebu (Saccharum Officinarum L.) Sebagai Bahan Ajar Kingdom Fungi Untuk Siswa Kelas X SMA. Jurnal Pendidikan: Teori, Penelitian, Dan Pengembangan, 1(10), 2023-2030. 
Nunilahwati, H., Herlinda, S., Irsan, C., \& Pujiastuti, Y. (2013). Eksplorasi, isolasi dan seleksi jamur entomopatogen Plutella xylostella (Lepidoptera: Yponomeutidae) pada pertanaman caisin (Brassica chinensis) di Sumatera Selatan. Jurnal Hama Dan Penyakit Tumbuhan Tropika, 12(1), 1-11.

Prayogo, Y. (2012). Sebaran dan efikasi berbagai genus cendawan entomopatogen terhadap Riptortus linearis pada kedelai di Lampung dan Sumatra Selatan. Jurnal Hama Dan Penyakit Tumbuhan Tropika, 6(1), 14-22.

Reddy, G. V., Antwi, F. B., Shrestha, G., \& Kuriwada, T. (2016). Evaluation of toxicity of biorational insecticides against larvae of the alfalfa weevil. Toxicology Reports, 3 , 473-480.

Rosmayuningsih, A., Rahardjo, B. T., \& Rachmawati, R. (2014). Patogenisitas Jamur Metarhizium anisopliae terhadap Hama Kepinding Tanah (Stibaropus molginus)(Hemiptera: Cydnidae) dari Beberapa Formulasi. Jurnal Hama Dan Penyakit Tumbuhan, 2(2), 28-37.

SOETOPO, D., \& Indrayani, I. (2015). Jamur entomopatogen Beauveria bassiana: potensi dan prospeknya dalam pengendalian hama tungau. Perspektif, 8(2), 65-73.

Suprayogi, S., Marheni, M., \& Oemry, S. (2014). Uji Efektifitas Jamur Entomopatogen Beauveria bassiana dan Metarhizium anisopliae terhadap Kepik Hijau (Nezara viridula L.)(Hemiptera; Pentatomidae) pada Tanaman Kedelai (Glycine max L.) di Rumah Kasa. Jurnal Agroekoteknologi Universitas Sumatera Utara, 3(1).

Yang, B., Qu, D., Zhang, X., Shen, J., Cui, S., Shi, Y., ... Meng, J. (2010). Prevalence and characterization of Salmonella serovars in retail meats of marketplace in S haanxi, China. International Journal of Food Microbiology, 141(1-2), 63-72. 